Aostract: Coraposite periphyton samples were collected in June 1985 from the MPC units 3 and 4 effluent holding ponds and from five locations along Cow Creek near Colstrip in Rosebud County, Montana. Diatom indicators and a relatively small number of diatom species show that the active cell, the solids and/or oxygen-demanding are stressed by dissolved solids, settleable the diatom flora of cow Creek and together with the homogeneous and hose of the effluent holding ponds, indicate little or no effect from creek.

A. CHPARISU.: U: ItE

\section{INTKODUCTION $\cdots$}

On May 7, 1985, the author proposed-to compare associations of benthic diatoms living in the Montana'Power Company (MPC) 'Colstrip Units $3 \& 4$ effluent holding ponds with those living in nearby Cow Creek, a tributary of Rosebud Creek in Rosebud County, Montana (Appendix A). Such comparison was intended as an additional tool to help determine whether there is a hydrologic connection between the ponds and the creek and, if there is, what effect seepage from the ponds might have on the biology of the creek. Using 1985 data as baseline, annual diatom monitoring may help to elucidate any long-term changes in Cow Creek biology that may be due to progressive salinization of and seepage from the effluent holding ponds.

\section{STATIONS}

Personnel from Hydrometrics collected samples on June 13, 1985, from the following holding pond locations:

1. Active Cell

2. Southeast Pond

3. Flyash Pond

4. Decant Pond
TO1N

Tolit

TUIN

T01N
R42E Section 6 DC

R42E Section $5 \mathrm{CC}-$ Blowdoun.?

R42E Section 6 DA

R42E

Section 6 Ad

Effluent is discharged to the active cell, from which it flows to the flyash pond and thence to the decant pond. The southeast pond has not been used for effluent disposal and the otner three ponds had not been dosed for about four weeks prior to sampling (Dan Shaffer, per. comn. 1985). 
.. Personnel from the MSU Reclamation: Research Unit collected samples June

3-o, 1985, from the following locations along Cow Creek:

. - a

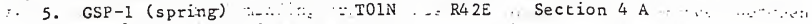

6. GSW-1-3 (creek).. TOLN. R42E Section $4 A$

7. GSW-3 (creek) TU1N R42E Section 3 A

8. GSN-5-3 (creek) $\because \operatorname{TO}$ TN R42E Section 2 D

9: GSW-6 (creek) $\because$ TOIN R43E Section 6 C

iLithesults alsolaretinoluded from ranalysis dEla s amplercollected by Dr. Duane Klarich -on Maý $20 ; 1979 ; \%$ at a site'on-lower Cow Creek:

10. Cow Creek near GSW-6 T01N R43E Section 6 DA

METHODS

$\therefore$ The procedure used to collect composite periphyton samples is described in Appendix B. Portions of conspicuous soft-bodied algae and a few drops of the well mixed sample were-placed-on.a microscope slide and scanned under low. power to identify the non-diacom algae present and to ascertain their abundance relative to the diatoms. The sample was then processed and a diatom proportional count was performed according to the procedures in Standard Me thods (A.P.H.A. et al., 1931).

Sinannon diversity (d) was calculated using the formula presented in weber (1973). Similarity between associations of diatons was determined by calculating Czekanowski's coefficient, as given in Hellawel1 (1978):

$$
C z=\frac{2 W}{A+B}
$$

where $\mathrm{W}=$ the sum of the lesser measures of abundance of each species conmon to both associations.

$A=\quad$ the sum of measures of abundance of species in association A

$B=$ the sum of measures of abundance of species in association $B$ 
0

10

(a) 


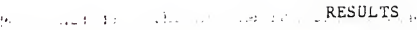

[n,

Diatoms were the dominant algae in all nine of the periphyton samples

collected for this study. Among samples from the MPC effluent holding ponds, only the one from the southeast pond contained any soft-bodied algae (Anabaena; Nodularia, Oscillatoria, Scenedesinus, Synechococcus). Common soft-bodied algae in the Cow Creek samples were Anabaena, Oedogonium, Oscillatoria, Phornidiun, Rivularia, and Tribonema.

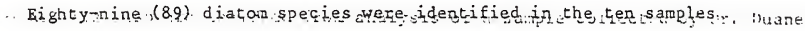
analyzed for this study, including the sample collected in 1979 (Appendix C). Diaton associations from the effluent holding ponds tended to have fewer species and smaller diversity values than those from Cow Creek (Table 1). Diatom species that dominate associations in the effluent holding ponds (Chaetoceros muelleri, Cylindrotheca gracilis, Nitzschia gandershiemiensis, and Nitzschia paleacea) are different from those that dominate associations in Cow Creek ( Navicula cryptocephaloides and Synedra famelica). Moreoever, each of the effluent holding ponds has a different dominant species, whereas all but one of the Cow Creek associations are dominated by the same species (Navicula cryptocephaloides).

Czekanowski coefficients for all station pairs (Taule 2) indicace considerable dissimilarity among associations from the effluent holding ponds. Average similarity among pond samples was 0.16 , compared to 0.46 among the Cow Creek samples. Average sirnilarity between pond and Cow Creek samples was only 0.08 . The association from the southeast pond was least like tnose of the other ponds (average similarity $=0.04$ ) and most like those of cow Creek (average similaricy $=0.15$ ). 
0

(1)

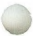


Table 1. Statistics for samples of benthic diatom associations collected frou the MPC effluent holding ponds and Cow Creek near Colstrip, June 1985.

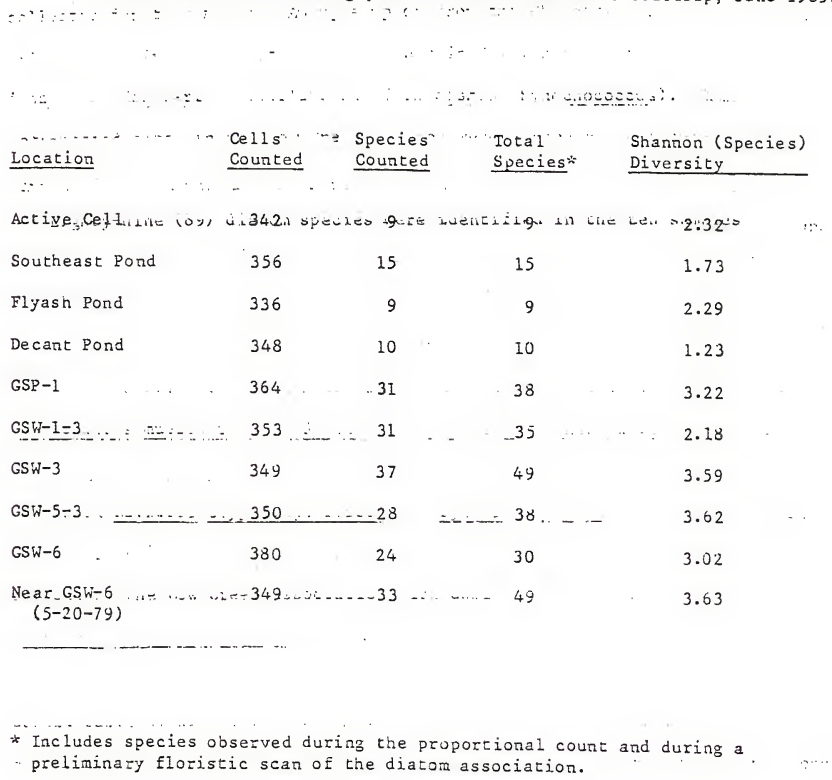


0

0 
Table 2. Values for czekanowski's coefficient for all station pairs

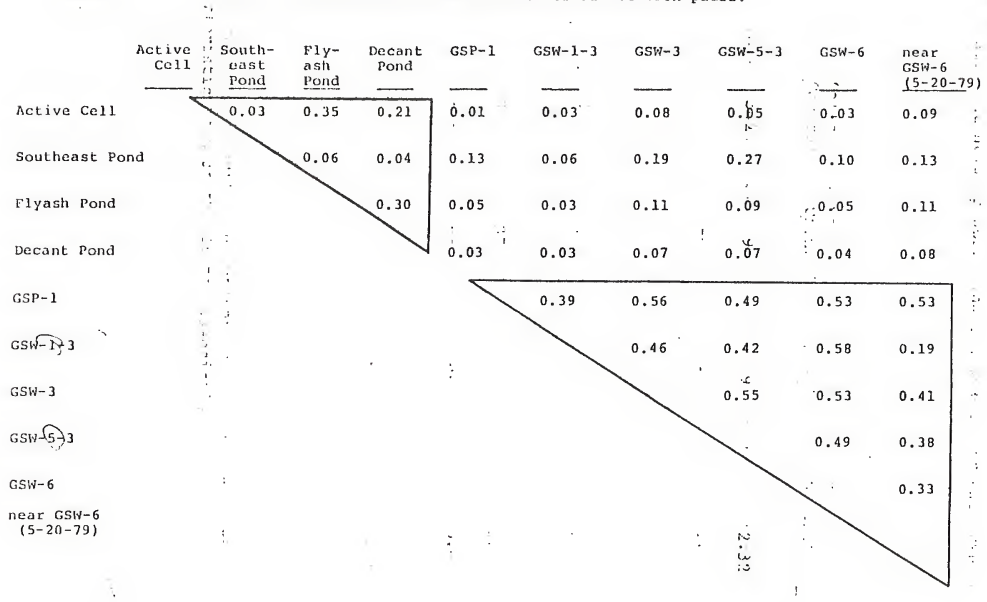


0

(1)

0 
DISCUSSION AND CONCLUSIONS

The relatively srall number of diatom species counted in the samples from the effluent holding ponds indicates enviromental-stress:-Bahts- $(19.79)$ reported that composite periphyton samples containing fewer than 21 species were typical of waters polluted by dissolved solids, heavy metals, organic wastes or inorganic nutrients. An examination of the water quality preferences of the most abundant species in the ponds may reveal the nature of

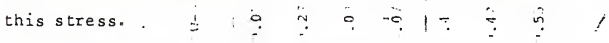

The largest population of Chaetocero's muelleri in Montana was reported from a small pond in Cascade County having a specific conductance of 26,620 umhos, while Cylindrotheca gracilis is morphologically adapted to maneuvering on unstable, muddy bottoms in aggrading habitat's (Bahls, 1982). Navicula tenelloides is a common species on saine seeps in Montana and has been found in waters having specific conductance values in excess of 40,000 unhos (Bahls and Bahls, 1978). - Lange-pertalot (1979) reports that Nitzschia gandersieimiensis develops large populations in waters subjected to very heavy loads of organic pollution. Thus, one may conclude that the active cell, the flyash pond and the decant pond are stressed by one or more of the following factors: dissolved solids, sectleable solids, and oxyzen-denanding organic wastes.

The active cell, flyash pond, and decant pond have specific conductance values ranging from 9,900 to 10,500 umnos; nitrite plus nitrate nitrogen measured about $0.5 \mathrm{mg} / 1$ in the active cell and flyash pond, but about $10 \mathrm{mg} / \mathrm{l}$ in the decant pond (Dan Shaffer, per. coran. 1985). This large concentration of inorganic nitrogen in the decant pond nay indicate an organic nitrogen precursor (other forms of nitzogen were not measured) and help to explain the presence of the very pollution-tolerant species Nitzschia yandersheimiensis. 


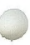

0 
The predominance of Nitzschia paleacea in the southeast pond, along with a moderate number: of Nitzschia communis, indicates less stress from dissolved solids. and organic wastes. . The optinum specific conductance values: for these species in southeastern Montana are less than 5,000 umhos (Bahls et al., 1984). Lange-Bertalot (19.79). reports that Nitzschia paleacea is less tolerant of organic pollution than Nitzschia gandersheimiensis.

Because the southeast pond has not been used for effluent disposal and tontains anly fresh-water runoff, it has not been sampled for water quality (Dan Shaffer, per. comr. 1985). This also explains why the algae flora of the southeast pond was inore similar to that of Cow Creek tinan. to the floras of the other three ponds. However, the smaller number of diatom species in the southeast pond (15) indicates moderate environmental stress, perhaps residual stress stemring from land disturbance at the time the pond was constructed and/or from diffuse (non-point) sources of contamination in the pond's

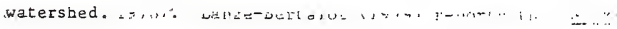

- The number of species counted in the Cow Creek samples indicates healthy diatom associations and only weakly stressed or unstressed conditions. The two dominant species -- Navicula cryptocephaloides (synonym: Navicula cincta var. in the southern Fort Union Coal Region of Uontana (Bahls et al., 1984); they tend to achieve their best population development at specific conductance values ranging from 5,000 to 6,000 umnos.

There appears to have been some reduction in diversity in the vicinity of GSi-6 between 1979 and 1985 (Table 1). However, a Shannon diversity value comparable to the 1979 value was recorded in 1985 at the next upstream station (Gs;-5). In Cow Creek, there will de soae year-to-year and station-to-station variation in diversity due to natural differences in weather, water quality substrate, and streamflow. Sampling error -- the deviation from a truly 
.

(

(2) 
representative sample.-- is an additional and unknown variable. As with most biological systems, several years of data will be needed to ascertain trends. sili.The very dissimilar floras of the effluent holding ponds and the Cow Creek sites together with the homogeneous and healthy Cow Creek diaton associations, indicate little or no effect from the ponds on water quality and biota in the creek. 7

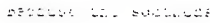

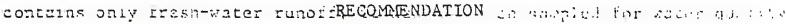

Samples should be collected again in early June of 1986 to continue a program of annual biological monitoring at these same locations in order to ... ascertain any changes in stream biota that may result from pond operation.

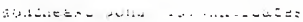

\section{ACKNOWLEDGE'AENTS}

A. Max Botz, Hydronetrics, arranged to have samples collected from the effluent holding ponds. Dan Shaffer, Hydrometrics, collected the samples. Frank Munshower, MSU Reclanation Research Unit, arranged to have samples collected from: Cow. Creek. . Fred-Shewnan, Water Quality Bureau, reviewed a draft of..this report.- Edwina Wheat typed the report. 
0

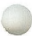


American Public Health Association, American Water Works Association, Water Pollution Control Federation. 1981. Standard Methods for the Exanination of Water and Wastewater, Fifteenth Edition. A.P.H.A, Washington, D.C.

.... $\quad 1: 2=\ldots$

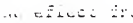
$-1,-\ldots, \ldots$ c...

Bahls, L.L. 1979. Benthic Diatom Diversity as a Measure of Water Quality. Proc. Mont. Acad. Sci. 38: 1-6.

Bahls, L.L. 1982. Eight New Diatom Genus Reçords for Momtana. Proc. Mont. Acad. Sci. 41: 79-86.

Bahls, L.L. and P.A. Bahls. 1978. Algal Populations in Seep-Affected Waters, With an Emphasis on Salinity Indicators and Potentially Toxic Species. In M. R. Miller et al., Regional As sessment of the Saline-Seep Problem and a Water Quality Inventory of the Nontana Plains. Montana College of Mineral Science and Technology, Butte.

Bahls, L.L., E.E. Weber and, and J.O. Jarvie. 1984. Ecology and Distribution of Major Diatom Ecotypes in the Southern Forr Union Coal Region of Montana. Geological Survey Professional Paper 1289. U.S. Government Pfinting Office, Washington, D.C:

Hellawel1, J.M. 1978. Biological Surveillance of Rivers. Natural Environment ... Research Council, Scevenase, Engiand.

Lange-Bertalot; Horst. 1979. Pollution tolezance of Diatoms as a Criterion for Water Quality Estimation. Nova Hedwigia, Beineft 64: 285-304.

Shaffer, Dan. Hydronetrics. Telephone conversation dated September 17, 1485.

Weber, C.I. (ed.) 1973. Biological Field and Laboratory Methods for Measuring the Quality of Surîace Waters and Effluents. EPA-670/4-73-001. 


0

$\rightarrow$ 


\section{DEPARTMENT OF HEALTH AND ENVIRONMENTAL SCIENCES}

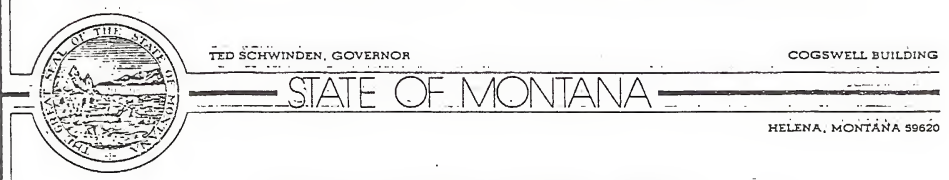

PROPOSAL TO MONITOR BENTHIC DIATOM $\ldots \ldots$

ASSOCIATIONS IN COW CREEK AND THE

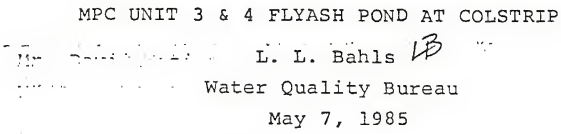

Background

Benthic diatoms are simple, microscopic plants (algae) that live on the bottoms of lakes, ponds and streams. A single collection of benthic diatoms may include up to 100 or more species, each with different ecological requirements. Diatoms are reliable indicators of salinity, nutrients, low dissolved oxygen, acidity, heavy metals, and other forms of pollution (Lowe, 1974). Bahis and others (1984) have described the water quality requirements of sixty-eight of the most common diatoms found in the southern Fort Union Region of Montana.

Rationale

Diatoms respond very guickly (in a matter of days or weeks) to changes in water quality. Certain groups or associations of diatoms are typical of different levels of salinity and different mixtures of ions. For example, some diacoms will live only in water dominated by calcium and bicarbonate ions; others will thrive only in waters where sulfate is the dominant anion. Minor constituents, e.g., boron, may also affect species composition of diatom associations in ways that are not yet understood.

This study proposes to use benthic diatoms to monitor water quality changes in Cow Creek and the MPC flyash pond at colstrip. It is an additional tool to determine whether there is a hydrulogic connection between the creek and the ash pond and, if there is, what effect seepage from the pond might have on the biolocy of the creek. The results would be interpreted in conjunction with those from hydrologic and vegetational studies. This work would complement those studies, not replace them. 


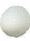

Q 


\section{Sampling Sites}

A single composite periphyton sample would be collected from each

- of three sites:

2. Upper Cow Creek at or near Hydrometrics' station GSiv-1

(TIN R42E Sec. $4 A B C$ ).

3. Lower Cow Creek at or near Hydrometrics' station GSW-6

(TIN R43E Sec. 6CCA). UU.. CNLLA ; H.t

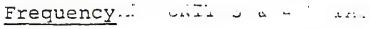

Periphyton samples woula.bé.collected once each year in late May or early June.

Methods

The procedure for collecting a composite periphyton sample is . outlined in the attached memo. Methods for processing periphyton samples are included in Standard Methods (15th Edition) and in Weber (1973). Collections from different stations will be compared using component (indicator) species and association diversity and similarity indexes.

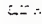

Max Botz," Hydrometrics, has agreed to arrange for sample collection if the Technical Comittee approves this proposal (telephone conversation with Ioren Bahls, May 3, 1985). Loren Bahls, WCB, would process the samples and report the results at no cost.

References

American Pubic Health Association et al. "1981. Standard Methods for the Examination of Water and Wastewater, Fifteenth Ecition. A.P.H.A., Washington, D.C.

Bahls, L.L., E.E. Weber and J.O. Jarvie. 1984. Ecology and Distribution of Major Diatom Ecotypes in the Southern Fort Union Coal Region of Montana. Geological Survey Professional Paper 1289. U.S. Government Printing office, Washington, D.C.

Lowe, R. I. 1974. Environmental Requirements and Pollution Tolerance of Freshwater Diatoms. EPA-670/4-74-005.

Weber, C.I. (ed.) 1973. Biological Field and Laboratory Methods for Measuring the Quality of Surface Waters and Effluents. EPA-670/4-73-001. 
0

(2) 
TO

- WATER QUALITY BUREAU FIELD PERSONNEL

DATE: June 20, 1977

FROH

LOREN BAHLS \&B

SUBJECT : PROCEDURE FOR COLLECTING COOMPOSITE PERIPHYTON SAMPLES FROM NATURAL SUBSTRATES

Periphyton consists. of the assemblage of plants and animals, mostly microscopic, living attached to or imediately upon the bottom of a body of water. The plants in this community of organisms are responsible for the. greater share of primary production in most Montana rivers and streams. These plants are usually algae, which often make the river or stream bottom slippery and slimy to the touch. Each kind of plant in the periphyton has specific environmental needs, allowing-for their use--singly or collectively--as biological monitors $\because$ of water quality.

The object in sampling periphyton from natural substrates is to obtain a collection of algae that is representative of the community from which it came. The algae should be present in the sample roughly in the same proportion as they exist in the stream. Different substrates-rock, silt, logs, higher aquatic plants--should be sampled 'In proportion to their importance as a substrate at a given station. Substrates exposed to different current velocities, depths, and shading should also be sampled, again roughly in proportion to the extent these conditions prevail at a site. (For example, if a section of stream to be sampled is 80 percent riffle and 20 percent pool, about 80 percent of the sample should come from riffles.)

Only a minimum of equipment is required: pocket knife, small bottles or vials with screw caps, labels, pen or pencil, and preservative. .. The following steps are recommended:

1. Fill sample container about half full of stream water, making sure the container is clean.

2. Collect individual filaments and colonies of macroscopic algae in proportion to their abundance relative one to another.

3. Carefully clean knife.

4. Scrape natural substrates as outlined in the previous paragrapin.

5. Add preservative (to retard bacterial growths), cap, and label.

Generally, only a few milliliters of periphyton make a sufficient sample. Most any available preservative is acceptable, including formalin (10\% formaldehyde), Lugol's (IKI), and ethanol. Lugol's, available from Abe Horpestad or myself, is preferred. You need add only enough to give a peranent red tint to the sample. No preservative is necessary if samples are delivered to the within 24 hours after collection. 
0

0

. 
WATER QUALITY BUREAU FIELD PERSONNEL

Page: 2 .

June 20, 1977

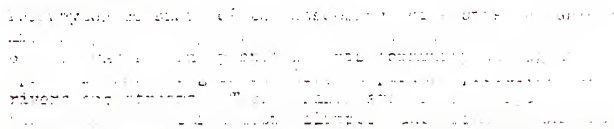

The sample should be labelled clearly with the date, the name of the water'sampled, a generaledescription of the sampling station, e.g.t, Tenmile Creek at USGS gaging station, the county in which the station is located and/or an accurate legal description including range, township, section, and.tract. Completion of a computer data card is not necessary unless water samples for chemical analyses are collected at the same time. Along with the samples, the sampler should include a note with the sampler's name, the name of the project (if any), and the desired deadine for completion of analyses and an interpretive report."

:

In addition to projects for which biological periphyton analyses have been budgeted, I would welcome samples from any uncollected waters in Montana. These samples will be used to determine the distribution and water quality relationships of individual diatom taxa in the state. If you are travelling, please check the map in my office. It shows where periphyton collections have already been made. If you plan on visiting an unsampled area, I will gladly furnish you with bottles, labels, and preservative. If you got the time, I've got the gear.

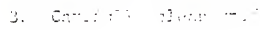




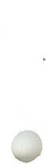

1

(1) 
Appendix C. Results of diaton proportional caunts (number of cells).

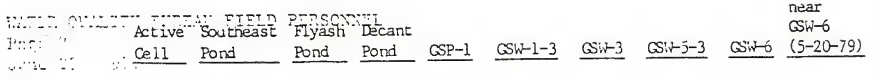

Acrnanthes hauckiana

Ainnanthes lanceolata

Achnanthes minutissina

inphipleura pellucida

Anpiora coffeifonnis

imphora ovalis

Anghora veneta

Anphora species A

hameoneis sphaerophor

Caloneis aminisbaena

Caloneis lewisii

Caloneis ventricosa

Caloneis species A

chaetoceros mulleri

Cocconeis placentula -

Cyclotella meneghiniana

Cylintrotheca gracilis

Cyrbella anzustata

Cymbella pusilla

Denticula elegans

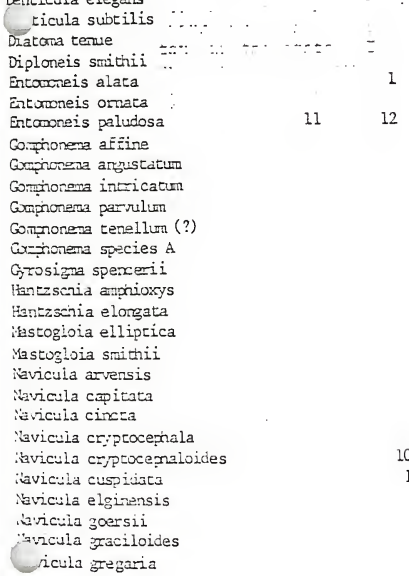

1

ana

28

21

2

$x$

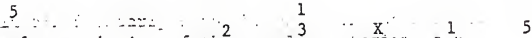

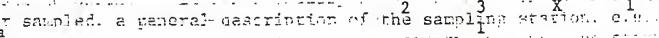

$\mathrm{X}$

1

1

$\mathrm{X}$

$69 x$

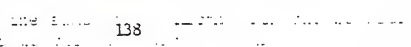

137

-. $\quad \frac{1}{4}$

3

...

$\mathrm{x}$ 
$\infty$

0 


\begin{tabular}{|c|c|c|c|c|c|c|c|c|c|c|}
\hline$\cdots$ & $\begin{array}{l}\text { Active } \\
\text { Cell }\end{array}$ & $\begin{array}{l}\text { Southesst } \\
\text { Pond }\end{array}$ & $\begin{array}{l}\text { Flyash } \\
\text { Pond }\end{array}$ & $\begin{array}{l}\text { Decant } \\
\text { Pund } \\
\end{array}$ & $\underline{\text { GSP-1 }}$ & $\operatorname{cs} \omega-1-3$ & $\cos N-3$ & SSit $-5-3$ & $\operatorname{cosin}-6$ & $\begin{array}{l}\text { near } \\
\text { S.N-6 } \\
(5-20-79) \\
\end{array}$ \\
\hline Navicula halophila & $\ldots \cdots:$ & $\vdots \ldots$ & $\because$ & . & 4 & 12 & & 5 & 6 & $\therefore 1$ \\
\hline $\begin{array}{l}\text { Navicula insociabilis } \\
\text { itavicula oblonga }\end{array}$ & it.... & $E_{0} x_{1}$ & $\therefore$ & $\therefore$ & $8=$ & $\therefore-1$ & $\therefore-3$ & $63-5$ & $\Leftrightarrow$ & $15-x \cdot$ \\
\hline Navicula pelliculosa & & & 1 & 10 & $\begin{array}{l}1 \\
2\end{array}$ & & & 1 & & $\begin{array}{l}x \\
1\end{array}$ \\
\hline Navicula peregrina :- & & & & & $\because$ & & & 3 & 6 & 6 \\
\hline Navicula perpusilla (?) & & & & & 1 & & & & & \\
\hline Navicula pyżaea & & & . & & ' & 2 & 1 & $x$ & 1 & $x$ \\
\hline :avicula salinarun & & & & & 1 & 1 & & 21 & 12 & 5 \\
\hline Navicula tenelloides & 98 & & 44 & 34 & 2 & 5 & 2 & 5 & 1 & 1 \\
\hline Navicula species A & 4 & $\because$ & & 1 & & 6 & $x$ & $x$ & & $x$ \\
\hline Novicula species-B & & & & & 1 & $\therefore$ & ? & $\mathrm{x}$ & . & \\
\hline Nitzschia acicularis & & & & & & & 2 & 6 & & 29 \\
\hline Nitzschia anphibia & & & & & 5 & & & & 1 & \\
\hline Nitzsenia apiculata & & 5 & & & $\mathrm{x}$ & 1 & 7 & $\mathrm{x}$ & $\mathrm{x}$ & 5 \\
\hline Nitzschia camunis & & 28 & & & & & & & & \\
\hline Witzschia elliptica & 12 & & 74 & 3 & $\mathrm{x}$ & & 1 & $\mathrm{X}$ & 1 & 1 \\
\hline Nitzschia frustulun & & 12 & & 2 & 45 & 2 & 28 & 5 & 69 & 21 \\
\hline Nitzschia gandershieniensis & 20 & & 39 & 272 & & & & & & \\
\hline Nitescinia gracilis & & & & & & & 15 & 4 & & 5 \\
\hline Nitzschia hunzarica & & 11 & & & & $\mathrm{x}$ & 1 & $\mathrm{x}$ & & 1 \\
\hline Nitzschia linearis & & & & & $\mathrm{x}$ & & & & & $\mathrm{x}$ \\
\hline Nitzschia ınicrocephala & & & & & 14 & 1 & 4 & 1 & 1 & \\
\hline :scria obtusa & & & & & & 15 & 1 & & 18 & $\mathrm{x}$ \\
\hline Nrzzschia palea & 30 & & 2 & 1 & 1 & 1 & 7 & 1 & $\because$ & 15 \\
\hline Nitzscria paleacea & 1 & 257 & 9 & 1 & 23 & 3 & 26 & 68 & 6 & 3 \\
\hline iNitzschia pusilla & & & & & & 3 & 1 & 7 & 1 & \\
\hline Nitzscria si:ma & & 2 & & & & & & & & \\
\hline Nitzscinia tryolionella & & & & & 1 & & $\mathrm{x}$ & & & \\
\hline Nitzschia vitrea & & & & & & & & 2 & 1 & $\mathrm{x}$ \\
\hline Pintularia microstauron & & 1 & & & & & 2 & & & \\
\hline Pleurusiston delicatulur & & & & & & & 1 & & & 9 \\
\hline Rhopelodia gibba & & & & & & $\mathrm{x}$ & & $\mathrm{x}$ & $\mathrm{x}$ & $\mathrm{x}$ \\
\hline Ropalodia rusculus & & 2 & & & $\mathrm{X}$ & 1 & 1 & $x$ & & 4 \\
\hline Surirella ovalis & & & & & $\mathrm{x}$ & $\mathrm{x}$ & 3 & & & $\mathrm{x}$ \\
\hline Surinella ovata & & 8 & & & & & & & & 2 \\
\hline Synecta acus & & & & & & & & $\mathrm{x}$ & & \\
\hline Synedra delicatissina & & & & & & 4 & & 15 & $\mathrm{x}$ & \\
\hline Synecra Fanelica & & & & & 100 & 14 & 15 & 34 & 29 & 108 \\
\hline Synecira Easciculata & & & & & & & 1 & 15 & 2 & 5 \\
\hline Synedra filiformis (?) & & & & & & & & 1 & & \\
\hline Synedra pulcriella & & & & & & & & & & $\mathrm{x}$ \\
\hline Sjnecra ulna & & & & & $\mathrm{X}$ & 2 & 1 & 3 & & \\
\hline
\end{tabular}

ibte: in " $\mathrm{X}$ " denotes a species that was exountered during a Gloristi a wan of the diaton slide but not during the proportional canc. 


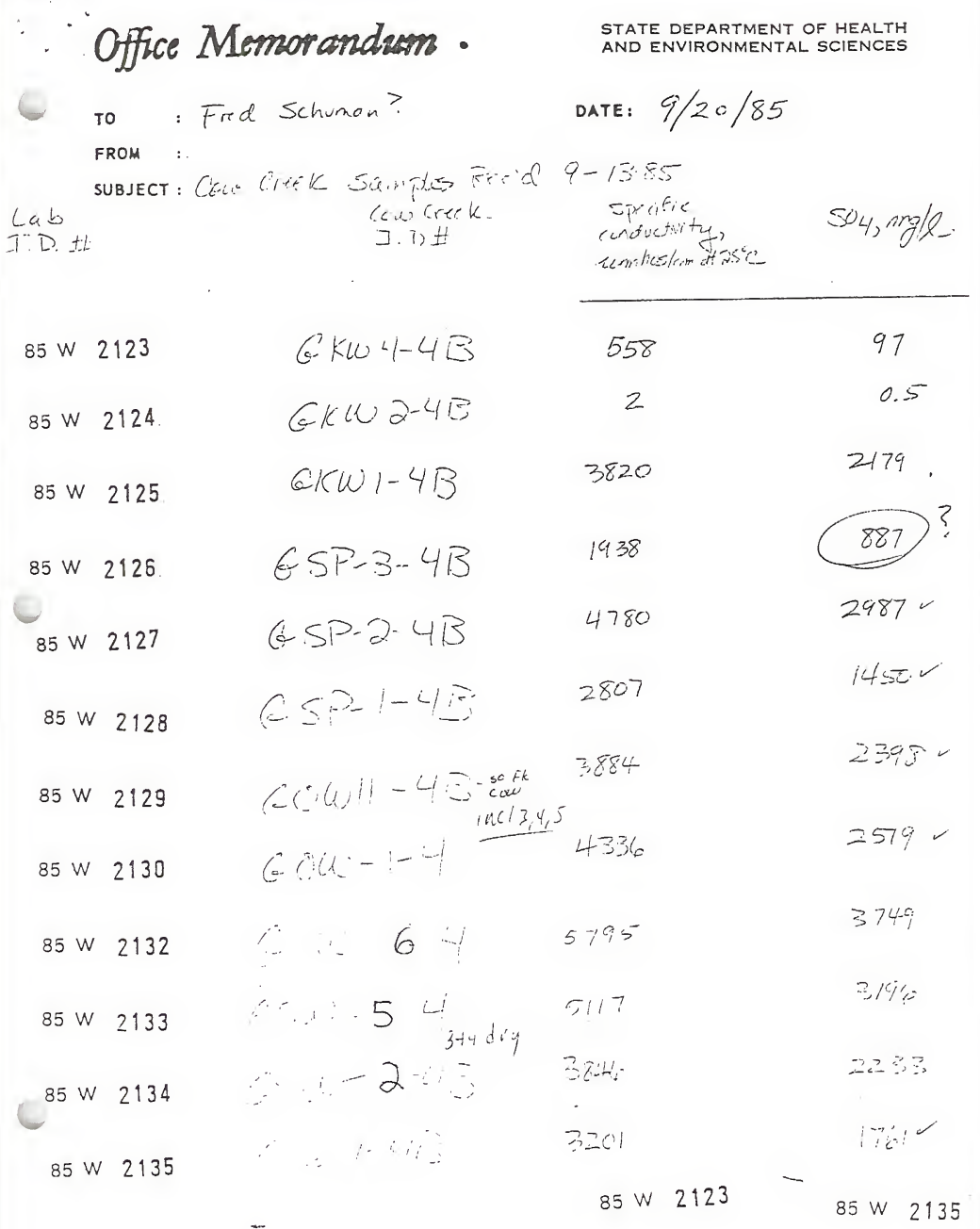




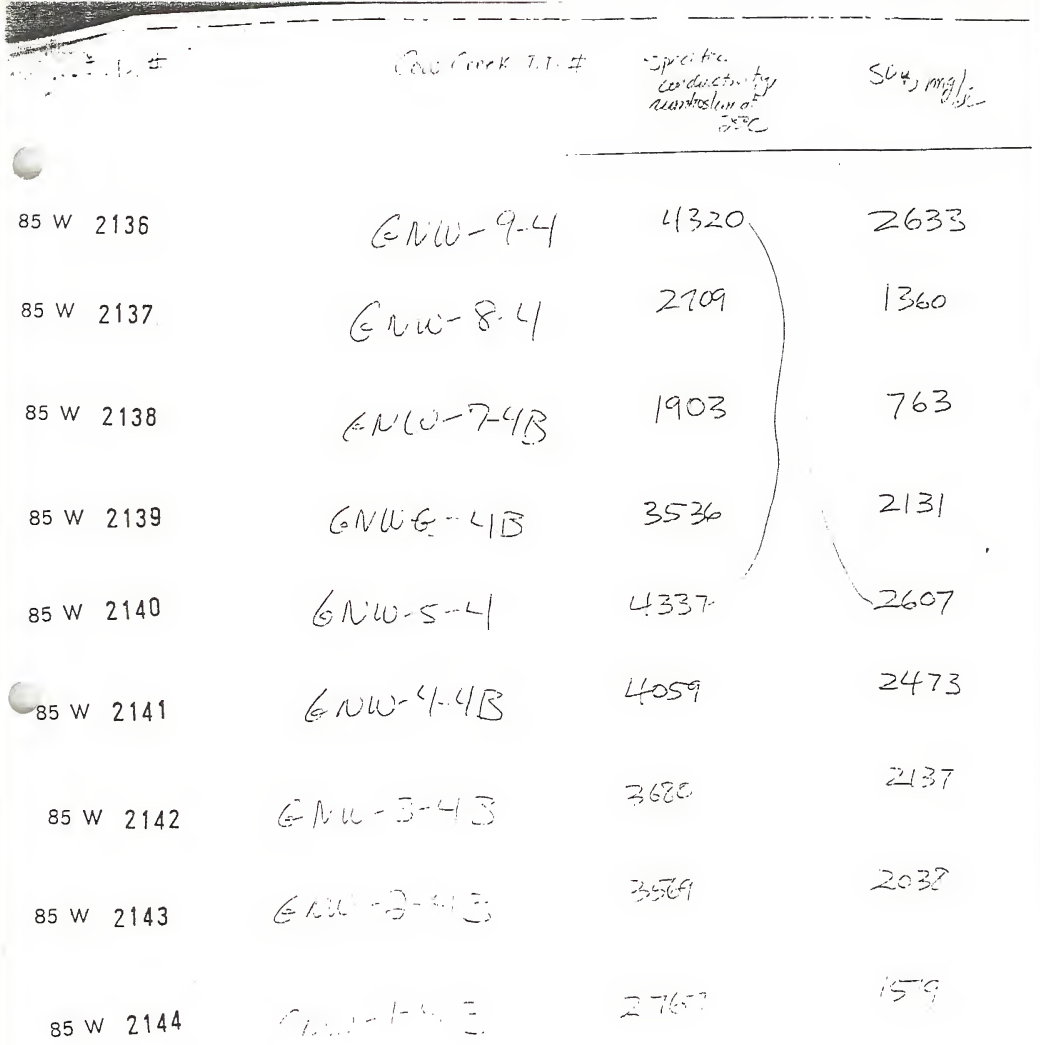


?

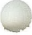

0 